\title{
Psychosocial explanations in research articles in Psychology: the Portuguese case and comments to Torres \& Neves
}

\author{
Joaquim Pires Valentim \\ Teresa Forte \\ Ana Figueiredo \\ University of Coimbra
}

\begin{abstract}
In the present paper we present a commentary on the talk given by Torres and Neves regarding the themes of research in Social Psychology in Brazil. This commentary focuses on issues of intercultural analyses referred to by these authors and their importance in the development of Social Psychology. We also aim to feed this debate with an illustration of the Portuguese scenario. Therefore, we present an analysis of the concepts, explanations and/or psychosocial analyses present in articles published between 2006 and 2012 in three Portuguese journals of Psychology (Análise Psicológica, Psicologia e Psychologica). The results show a high predominance of the "systems external to individuals", especially the ones related to systems of categorization and/or social identities in groups of different social status (Doise, 2012). These results are discussed, synthetically, in articulation with the defence of "cultural translation" as proposed by Torres and Neves.
\end{abstract}

Keywords: cultural analysis; Social Psychology in Brazil; explanations in social psychology; levels of analysis; Portuguese psychology journals.

\section{Resumo}

Explicações psicossociais em artigos de Psicologia: o caso português e comentários a Torres e Neves. Apresenta-se aqui um comentário à intervenção de Torres e Neves sobre os temas de pesquisa em psicologia social no Brasil. Este comentário foca-se nas questões de análise intercultural referidas por aqueles autores e da sua importância no desenvolvimento da psicologia social. Procura também alimentar este debate com uma ilustração do que se passa no cenário português. Assim, apresenta-se uma análise aos conceitos, explicações ou análises psicossociais presentes nos artigos publicados entre 2006 e 2012 em três revistas portuguesas (Análise Psicológica, Psicologia e Psychologica). Os resultados mostram uma grande predominância dos "sistemas externos aos indivíduos", em especial daqueles que se relacionam com sistemas de categorizações e/ou de identidades sociais de grupos com diferente estatuto social (Doise, 2012). Estes dados são discutidos, de forma sintética, em articulação com a defesa da "tradução cultural" que Torres e Neves fazem.

Palavras-chave: análise cultural; Psicologia Social no Brasil; explicações em psicologia social; níveis de análise; revistas portuguesas de psicologia.

$\mathrm{W}$ e begin by noting a distinction between the path that Brazilian Social Psychology has taken and what has happened in other scenarios. This appears clearly in the text of Torres and Neves, when they say that, in Brazil, "until the seventies there was a predominant influence of American Social Psychology" and that later its development was marked by two trends, one more empiricist, and another more Marxist and socio-historically oriented. This is not - and this was not - the course of development of Social Psychology in Portugal. Nor was its development within what is usually called European Social Psychology. In the first case, in Portugal, we are very far from that longevity seen in Brazil and it is not an exaggeration to say that until the beginning of the 70 s of the last century, there was almost a desert in terms of research in Social Psychology. Furthermore, for other reasons, the situation is also different in Europe, where Marxist and socio-historical approaches, are not prominent as they are in Brazil (Batur, 2011; Doise, 2011a, 2011b).

In the comment on "Brazilian Social Psychology in the international context" we will return to this point. For now, having made this first observation, we move on to another issue, about which we are clearly in agreement with Torres and Neves - and we rarely see being discussed - the need to exercise the ability of translation in Social Psychology research. But not a 
linguistic translation, usually coined a "translation of the English language which, after all, can be considered as the lingua franca of the area, or the Latin of our times. What is needed is a cultural translation" the authors state (author's italics). We underline the importance of this point. In fact, the problem exists and persists. In 1963, Festinger spoke of the need for change "from a 'United States Social Psychology' to a 'Social Psychology of human beings"” (cf. Moscovici \& Marková, 2006, p. 16). And his position was very clear: 'one cannot simply 'repeat' a procedure in another country with another language and a different culture. One has to 'translate' the procedure. Then how does one know to what extent agreement or lack of agreement in the results of the studies is due to lack of cleverness or too much cleverness in the 'translation'?" (Festinger, cit. in Moscovici \& Marková, 2006, pp. 19-20).

As Moscovici and Marková (2006, p. 20) state about the inverted commas used by Festinger around the word "translation", "he was not concerned with the literal translation of words from one language to another one, but with the translation of cultural and symbolic significances that are more than the meanings of the words". Or, in other words, as Torres and Neves say, what is necessary "is a cultural translation".

And this brings us to another point that also affects us directly, both in research in Portugal and in the European context, and one which Torres and Neves affirm very well, when they say that "it is necessary to clarify the concept of culture". In fact, this can be - and from our point of view, should be - a central concern of the research conducted in this field. Especially, given that sometimes cultural variables are no more than variables invoked retrospectively to explain what our theoretical tools and analysis schemes fail to explain. That is, in these cases, cultural variables are nothing more than a frame that says little or nothing and that, taken literally, leads us to a contextualism of doubtful accuracy.

Moreover, in intercultural analysis, we should always remember that there is much intracultural variability, as there is much diversity within each culture, including social differences. Different cultures are far from homogeneous and if we forget this we may run a double risk. First, losing the rigour of the psychosocial study of culture. Secondly, in terms of knowledge dissemination, the knowledge thus produced lends itself easily to processes of stereotyping, of homogenizing the outgroup and even essentializing and discriminating against others. Although there may be a methodological and analytical need to "temporarily suspend" the recognition of intracultural diversity in cultural analysis, this diversity must be reintegrated within the research framework and theoretical analyses. In fact, the importance of overcoming ethnocentrism in Western research on topics of Social Psychology seems to beg a need for a renewed rigor and even some caution in the analysis and cultural explanations so as to prevent them from becoming the fuel of identitary and essentialist drifts.

That said, we move directly to the second part of our intervention, in which we present work in the wake of the various analyses of scientific literature in Social Psychology that several Brazilian colleagues presented in this Symposium. Indeed, the frequency of this type of data at the Symposium, seemed to us so relevant and useful that it led us to look for information of this nature that could fuel the debate. Thus, following a challenge in another context by Willem Doise to the first author of this article, we decided to try to come up with an analysis like the one Doise (2012) recently made of articles published between 2006 and 2010 in the Italian journal Psicologia Sociale.

Our analysis focused on journals in Psychology, because in Portugal there is none specifically within the domain of Social Psychology. The journals we have selected are Análise Psicológica, Psicologia and Psychologica. The reason for this choice is simple: these are among the most consistent in terms of continuity over time, from the beginning of their publication (Análise Psicológica in 1977, Psicologia, in 1980 and Psychologica in 1988) until now, and because, simultaneously, these are the Portuguese journals that in 2012 were best rated in Psychology in Qualis (B1).

To make a parallel with the study of Doise regarding Italian articles, we decided to start the analysis from the same year (2006) and extend it to the present. That is, our analysis extends to the last issues of each of the journals published until September 2012: numbers 30(3) of Análise Psicológica, 26(1) of Psicologia and 55 of Psychologica.

Given that none of the journals is specifically about Social Psychology, we had to decide what articles to retain. This was one of the greatest difficulties. We tried to include all the articles that use concepts, explanations or analyses of Social Psychology. We used the following criteria to retain an article: 1) it focuses explicitly on Social Psychology, 2) it uses key concepts of the discipline as central concepts in their content, and 3) it uses as key references works that are clearly within the scope of Social Psychology. But, faced with the need to define the contents, the task is far from simple. We therefore resorted to the method of inter-judge agreement, these being the three authors of this article. First, they proceed to the categorization in an independent way. After, there were several discussion meetings to seek consensus in cases where there was no agreement. When this was not reached, the decision was made by majority vote.

We must bear in mind that we used a relatively broad perspective in the selection of articles. That is, a filter that focuses on descriptions, explanations and analyses that use concepts and theories of Social Psychology and does not focus exclusively on studies that explicitly reside in the field of Social Psychology. In doing so, we were faced with many interfaces and neighbouring areas with articles of adjacent disciplines and areas that use, in a more or less diffuse way, concepts of Social Psychology. This may have led to a somewhat "imperialist" framework in relation to studies of other research areas, especially within the field of work and organizational Psychology and justice or forensic Psychology. However, in the cases in which we were dealing with articles from other areas, we always used a defensive criterion, so as to avoid including in our analysis something that might not be considered Social Psychology. We analysed 74 articles, 28 from Análise Psicológica, 23 from Psicologia and 23 from Psychologica.

In the classification of articles, we used the categorization 
that Doise recently used in his analysis of articles published in the Italian journal Psicologia Sociale (Doise, 2012; Doise \& Valentim, in press n.d.). This categorization differentiates among systems "external" to individuals and systems "internal" to individuals.

The "external" systems refer to variables that "belong to systems or structures present in the social environment and that, somehow, organize this environment before the subjects studied in research are involved in it" (Doise, 2012, p. 150). These systems include: a group with the systems of categorization and / or social identities that include links between identities and relations between groups with different social status (e.g., studies of social representations that take into account the status of the groups or their different social positions); a second group relating to family ties, nearby people or educational institutions (e.g., studies that focus on programs of attitude modification); a third group focused on interactions between individuals (e.g., studies addressing intragroup conflicts); and finally, one last system concerning aspects of political discourse (e.g., studies that focus on social discourse about State action).

The "internal" systems comprise two groups: one concerning motivations and cognitions (e.g., studies that focus on decision making), and the other referring to motivations and cognitions associated with actions (e.g., studies that focus on attitudes and manifest behaviours)

In the way we used this categorization, we tried to maintain the distinction between analysis markedly focused on intraindividual processes and others that refer to an "ideological" level of analysis, as framed by Doise (1982). Thus, for example, studies that explicitly involve values, social representations and analysis of cultural nature were included in systems originating "outside" the individual, and generally clustered in the group "systems of categorizations and / or social identity". We recognize that this option is debatable and we do not intend, in any way, to feed the old internal/external dichotomy within this domain. We have done so only for purely operational purposes, so as to maintain the distinction present in Doise (1982) between the intra-individual and ideological levels that we deem relevant and which otherwise would be lost in our analysis.

Another difference in relation to Doise's work (2012) is that, in our analysis, we did not always classify each article in only one category, because sometimes we found, in the same article, studies that focused on more than one of those six categories. Actually, in the 74 articles analysed, we found 107 occurrences in the classification system used.

Regarding our results, the most relevant fact is the large predominance of systems "external" to the individual and that a large majority of these relate to "systems of social categorizations and/or social identity" (Table 1). The systems considered more "internal" to the individual (cognitions and motivations) are around a quarter of the total of occurrences found.

Note should also be taken of the presence of a very small number of studies that relate to "aspects of the political discourse" (4.7\% overall and $6.3 \%$ of the "external systems"). Especially since, as we said above, we adopted an expanded grid in the selection of articles, by including investigations in areas

Table 1

Frequencies in Each Category, by Journal and in the Total of Analysed Articles

\begin{tabular}{|c|c|c|c|c|c|}
\hline System (Doise, 2012) & $\begin{array}{c}\text { Análise } \\
\text { Psicológica }\end{array}$ & Psicologia & Psychologica & Total & $\%$ \\
\hline $\begin{array}{l}\text { "External" } \\
\text { Categorizations, social identities/groups with }\end{array}$ & 12 & 15 & 14 & 41 & 38.3 \\
\hline $\begin{array}{l}\text { different status } \\
\text { Family, nearby people and educational institutions }\end{array}$ & 6 & 4 & 4 & 14 & 13.1 \\
\hline Interactions between individuals & 7 & 5 & 7 & 19 & 17.8 \\
\hline Political discourse & 3 & 2 & 0 & 5 & 4.7 \\
\hline Total & - & - & - & 79 & 73.8 \\
\hline $\begin{array}{l}\text { "Internal" } \\
\text { Cognitions and motivations }\end{array}$ & 9 & 5 & 6 & 20 & 18.7 \\
\hline Cognitions and motivations associated with actions & 3 & 4 & 1 & 8 & 7.5 \\
\hline Total & - & - & - & 28 & 26.2 \\
\hline
\end{tabular}

adjacent to social psychology. What causes the studies published in Portugal to address this issue so little? We do not know the answer to this question. But it should be noted that in Doise's analysis of the articles published in the Italian journal Psicologia Sociale, these systems (although more present than in Portuguese journals) are also the ones with the lowest overall percentage, at $8.48 \%$ (and $12.5 \%$ of systems external to the individual). We do not know to what extent the theme of political discourse is more or less present in Brazilian Social Psychology. But judging from the presentations of our Brazilian colleagues in this Symposium, several of these make clear the richness and diversity of topics covered, and it may be that it is not such an absent theme in Brazilian studies as it is in Portuguese studies.

Returning to the main point of our results, a domain as large as the one of "systems external to the individual" can have many interpretations. One is the difficulty (or even impossibility) of publishing such studies in the most prestigious international journals, which nowadays are usually published in English. 
Clearly we do not have data that could preclude the idea that this can also be attributed simply to reasons of intrinsic quality of the articles that would make their authors, for different reasons, "keep" this type of study for Portuguese journals. To answer this question we would have to undertake other types of analysis, focusing also on the patterns of publications in international journals published by the same authors of the studies analysed.

But we cannot exclude the possibility that these results are due to the fact that these articles, which focus on problems and issues that search for links with these "external systems", may not be easily accepted - or so their authors decide - in other journals. This may also have its roots in the cultural and even national specificity of the subjects studied. And this being the case, we could be dealing here with an expression of this fact that Torres and Neves raised so well by saying at the end of their presentation that "not everything that is produced in approximately one fifth of the world (...) directly applies to the remaining 4/5 of the world".

Our results regarding internationalization, considering authors' institutional affiliation by article (Table 2), can also be read accordingly. Internationalization is low. Most of the articles published have only authors with Portuguese institutional affiliation. And it should be noted that no article has Portuguese and Brazilian co-authors.

Summarizing, these are the two main points of our results: first, the great predominance of studies that go beyond the intraindividual level, making "systems external to the individual" intervene and, secondly, a low level of internationalization. Considered simultaneously, these two points can take us back to the need for a "cultural translation" as defended by Festinger and also underlined by Torres and Neves, or to the need to overcome a production of psychosocial research limited to "about $1 / 5$ of the world."

To achieve this, Festinger argued for the intensification of "interaction with, and opportunities for research for social psychologists in widely diverse places so that within each country there are indigenous research programs developed, sparked by the ideas which the local investigator has and nourished by theoretical interaction with psychologists in other countries" (cited by Moscovici \& Marková, 2006, p. 17). That is precisely what Brazilian colleagues are doing with this Symposium here in Brasília. And, from our point of view, doing it very well. Because we believe that Festinger's arguments remain valid and this is a path that must be followed and intensified.

Table 2

Authors'Institutional Affiliation by Article $(n=74)$ in the Three Journals

\begin{tabular}{|c|c|c|c|c|c|}
\hline \multirow{2}{*}{ Authors' affiliation } & \multicolumn{3}{|c|}{ Journal } & \multirow{2}{*}{ Total } & \multirow{2}{*}{$\%$} \\
\hline & Análise Psicológica & Psicologia & Psychologica & & \\
\hline Portuguese & 25 & 15 & 17 & 57 & 77 \\
\hline Portuguese and foreign & 2 & 2 & 0 & 4 & 5.4 \\
\hline Foreign & 1 & 6 & 6 & 13 & 17.6 \\
\hline [Brazilian] & [1] & [1] & [2] & [4] & [5.4] \\
\hline
\end{tabular}

\section{References}

Batur, W. (2011). Marxism, Social Psychology and Marxist Social Psychology. In J. P. Valentim (Ed.), Societal approaches in Social Psychology (pp. 107127). Berne: Peter Lang.

Doise, W. (1982). L'explication en psychologie sociale. Paris: Presses Universitaires de France.

Doise, W. (2011a). Deux psychologies sociales marxistes dans l'Allemagne de l'époque du Mur de Berlin - Partie I: à l'Est. Psicologia e Saber Social, l(1), 5-21.

Doise, W. (2011b). Deux psychologies sociales marxistes dans l'Allemagne de l'époque du Mur de Berlin - Partie II: à l'Ouest. Psicologia e Saber Social, 1(1), 22-39.

Doise, W. (2012). Sistemi e metasistemi negli articoli di ricerca di Psicologia Sociale (2006-2010). Psicologia Sociale, 1, 149-158.

Doise, W., \& Valentim, J. P. (in press). Explanations in Social Psychology. In International Encyclopedia of Social and Behavioral Sciences (2nd edition). Oxford: Elsevier.

Moscovici, S., \& Marková, I. (2006). The making of modern social psychology. The hidden story of how an international social science was created. Cambridge: Polity Press.

Joaquim Pires Valentim, $\mathrm{PhD}$ in Social Psychology at the University of Coimbra and also the European $\mathrm{PhD}$ on Social Representations and Communication, professor at Faculty of Psychology and Educational Sciences of the University of Coimbra. He did his main research focus is on the fields of social representations, intergroup relations, cultural diversity and social justice. Sponsored by the Coordination for the Improvement of Higher Level -or Education- Personnel (CAPES) and University of Brasília . E-mail: jpvalentim@fpce.uc.pt Teresa Forte, master's degree in Psychology from the University of Coimbra, researcher at the Faculty of Psychology and Educational Sciences of the University of Coimbra. Her main research interests are in the field of social representations.

Ana Mateus Figueiredo, PhD in Social Psychology at the University of Coimbra and the University of Amsterdam, received her European PhD title in 2012. Researcher at the Faculty of Psychology and Educational Sciences of the University of Coimbra. Her main research interests are in the fields of intergroup relations and conflict, emotions and social representations. 